\title{
РОЛЬ ИНФОРМАЦИОННЫХ СИСТЕМ В ЭКОНОМИЧЕСКОЙ БЕЗОПАСНОСТИ РОССИЙСКОЙ ФЕДЕРАЦИИ
}

\section{Савинская Дина Николаевна \\ к.э.н., доцент}

Барышева Дарья Николаевна

студент

ФГБОУ ВО «Кубанский государственный аграрный университет имени И.Т. Трубилина»

\begin{abstract}
Аннотация: в связи с процессом цифровизации экономики все более значимым становится внедрение информационных систем в экономические процессы. Вместе с тем увеличивается и такой вид экономической преступной деятельности, как киберпреступность. В статье рассматривается роль информационных технологий, важность их применения и улучшения для предупреждения и выявления кибератак на ранних стадиях, а также повышения уровня экономической безопасности страны.
\end{abstract}

Ключевые слова: информационные технологии, экономическая безопасность, преступность, кибератаки, эффективность экономики.

\section{THE ROLE OF INFORMATION SYSTEMS IN ENSURING THE ECONOMIC SECURITY OF THE RUSSIAN FEDERATION}

\author{
Savinskaya Dina Nikolaevna \\ Barysheva Daria Nikolaevna
}

\begin{abstract}
: in connection with the process of digitalization of the economy, the introduction of information systems into economic processes is becoming increasingly important. At the same time, such type of economic criminal activity as cybercrime is also increasing. The article examines the role of information technologies, the importance of their application and improvement for the
\end{abstract}


prevention and detection of cyber attacks at an early stage, as well as improving the level of economic security of the country.

Key words: information technologies, economic security, crime, cyber attacks, economic efficiency.

Сегодня во всем мире экономическая преступность приобретает информационно-технический характер. Именно поэтому в последние годы использование современного оборудования и информационных технологий рассматривается как ориентир для развития экономической деятельности и обеспечения экономической безопасности.

Проникновение цифрового обеспечения способствовало тому, что экономическая деятельность предприятия больше не ограничивается территориальными рамками и приобретает мировой масштаб.

Сетевая экономика позволяет всем интегрироваться в мировое пространство и при этом держать конкурентную борьбу. Предприниматели в современных условиях работают в динамичной глобальной среде, и эффективность их решений становится все более зависимой от своевременного предоставления и точной обработки информационных потоков [1]. Цифровые системы позволяют экономить время, сокращать издержки планирования и управления. Все это повышает прибыльность организаций, их производительность и эффективность работы [2].

Параллельно с данными процессами информационные технологии также позволяют более оперативно реагировать на различного рода спекулятивные атаки, несущие угрозу экономической безопасности страны.

Как уже было отмечено ранее, преступность приобретает информационно-технических характер. Причиной тому является хранение отчётности и информации в основном в электронном виде, вследствие чего увеличивается угроза конфиденциальности информации. По данным МВД России число кибератак за последнее время сильно возросло, в том числе из-за пандемии, поскольку большинство занятых переориентировалось на дистанционный формат работы [3].

Состояние киберпреступности в Российской Федерации на 2021 год отражено в таблице 1. 
Таблица 1

Состояние преступности на 2021 год в Российской Федерации [3]

\begin{tabular}{|c|c|c|c|c|c|}
\hline & \multicolumn{2}{|c|}{$\begin{array}{c}\text { Зарегистрировано } \\
\text { (в отчетном периоде) }\end{array}$} & \multicolumn{3}{|c|}{$\begin{array}{c}\text { Из числа преступлений, дела и } \\
\text { материалы, о которых находились в } \\
\text { производстве: }\end{array}$} \\
\hline & Всего &,+- в $\%$ & Всего &,+- в \% & $\begin{array}{l}\text { Раскрываемость } \\
(\%)\end{array}$ \\
\hline $\begin{array}{c}\text { Всего } \\
\text { преступлений }\end{array}$ & 1188075 & $-0,1$ & 622587 & 0,9 & 56,7 \\
\hline $\begin{array}{c}\text { Совершенных с } \\
\text { использованием } \\
\text { информационно- } \\
\text { телекоммуникацио } \\
\text { нных технологий } \\
\text { или в сфере } \\
\text { компьютерной } \\
\text { информации } \\
\end{array}$ & 315671 & 15,7 & 77774 & 46,4 & 27,0 \\
\hline \multicolumn{6}{|l|}{ из них: } \\
\hline $\begin{array}{l}\text { - тяжких и особо } \\
\text { тяжких }\end{array}$ & 179455 & 29,2 & 52682 & 64,6 & 32,6 \\
\hline $\begin{array}{c}\text { - совершенных с } \\
\text { использованием } \\
\text { или применением } \\
\text { расчетных } \\
\text { (пластиковых) карт }\end{array}$ & 103796 & 2,3 & 25255 & 33,3 & 25,5 \\
\hline $\begin{array}{c}\text { - совершенных с } \\
\text { использованием } \\
\text { или применением } \\
\text { фиктивных } \\
\text { электронных } \\
\text { платежей } \\
\end{array}$ & 922 & 25,4 & 364 & 75,0 & 48,9 \\
\hline - сети «Интернет» & 212807 & 36,6 & 50652 & 68,5 & 26,8 \\
\hline \multicolumn{6}{|l|}{ в том числе: } \\
\hline - кража & 98070 & 4,5 & 25606 & 73,1 & 27,1 \\
\hline - мошенничество & 137903 & 8,2 & 12718 & $-5,5$ & 10,1 \\
\hline
\end{tabular}

Исходя из данных таблицы 1 отмечается прирост количества зарегистрированных IT-преступлений $(+15,7 \%)$ за январь-июль 2021 года по сравнению с аналогичным периодом предыдущего года, их удельный вес составляет $26,6 \%$ от общего числа преступлений. При этом киберпреступления имеют один из самых низких процентов раскрываемости $(27,0 \%)[3]$. 
Рост Интернет-мошенничеств и их более трудная идентификация оказывают существенное влияние на состояние экономической безопасности. Об этом говорит падение их раскрываемости на 5,5\% [3]. По данным ЦБ РФ, количество операций без клиентского согласия выросло на 40\% [4]. Объем уведенных денег превысил показатели предыдущего года на 57\%, составив около 3 млрд. руб. только за I квартал 2021 года.

Существующая статистика указывает на необходимость раннего выявления и предотвращения атак злоумышленников благодаря IT-технологиям. Это возможно при помощи улучшения средств идентификации и аутентификации пользователей, улучшения антивирусной защиты, системы управления доступом к информационной системе.

Также в целях повышения экономической безопасности предприятий следует использовать различные информационные продукты, позволяющие вести учет разных параметров предпринимательской среды, неудачных и удавшихся попыток кибернападений на интеллектуальную собственность, хранилища данных. Это позволит проводить ретроспективный анализ, выявлять слабые места и разрабатывать стратегии улучшения имеющихся параметров и системы безопасности.

Немаловажное значение информационных систем в обеспечении эффективности экономики заключается в повышении управляемости социально-экономическими процессами предприятия. Отдельные элементы производства оптимизируются и налаживается деятельность в целом. Помимо этого, цифровые технологии расширяют спектр сфер занятости населения, увеличивают количество рабочих мест, а следовательно, способствуют снижению уровня безработицы, уменьшая тем самым девиантное поведение, что положительно сказывается на экономической безопасности субъекта.

Таким образом, роль цифровых систем в экономике очень велика, их развитие приносит огромное количество преимуществ для всех агентов экономики, позволяя сокращать издержки производства и сроки проектирования, обеспечивать точность в расчетах, максимизировать прибыль и снижать риски.

Однако вместе с тем продолжают развиваться также и новые, все более изощренные способы мошенничеств и краж. Анализ последних 2 лет показал, что в России количество экономических преступлений в сети имеет тенденцию к росту. Это говорит о необходимости совершенствования информационных систем, внедрении инноваций. Сегодня в качестве защиты 
данных выступают операционные системы компьютера, а также различные антивирусные программы. Для большей уверенности в защищенности информации можно отойти от использования иностранных операционных систем, таких как Windows, Linux, в пользу альтернативных российских, которые на данный момент нуждаются в доработке. На государственном уровне необходимо поддерживать и стимулировать отечественных разработчиков-программистов. На уровне субъекта экономики немаловажно заметить, что каждый человек или организация могут обезопасить себя и страну от утечки данных путем более осторожного и предусмотрительного их предоставления. Все это позволит более эффективно реагировать на кибератаки и предотвращать угрозы еще на стадии их формирования. Применение и улучшение электронных технологий является одним из основных требований для безопасного хранения, обработки и передачи данных.

\section{Список литературы}

1. Балдин К.В. Информационные системы в экономике : учебник / К.В. Балдин, В.Б. Уткин. - 7-е изд. - Москва : Дашков и К, 2017. - 395 с. — ISBN 978-5-394-01449-9. — Текст : электронный // Лань : электронно-библиотечная система. — URL: https://e.lanbook.com/book/93391 (дата обращения: 26.09.2021). — Режим доступа: для авториз. пользователей.

2. Российская наука: актуальные вопросы, достижения и инновации. Материалы всероссийского конкурса научных работ. - Краснодар, Издательство: Краснодарский ЦНТИ - филиал ФГБУ «РЭА» Минэнерго РФ, 2020. $-235 \mathrm{c}$.

3. Отчет Министерства внутренних дел РФ. Состояние преступности в России за январь-июль 2021 года // [Электронный ресурс] // URL: https://media.mvd.ru/files/application/2202989.

4. Отчет Банка России. Обзор отчетности об инцидентах информационной безопасности при переводе денежных средств // [Электронный ресурс] // URL: http://cbr.ru/analytics/ib/review_1q_2021/. 